\title{
Asymmetry of Kazakh velar and uvular consonants
}

\author{
Heather Lynn Yawney \\ University of Toronto
}

Little descriptive work has been done on the place and voicing restrictions of the asymmetrical velar and uvular consonant inventory in Kazakh. In Kazakh, velar and uvular consonants are restricted depending on their neighbouring vowel. Velars appear in front vowel environments and uvulars appear in back vowel environments (place restriction). Voiced and voiceless velars and uvulars are restricted depending on their position in the word. At the morpheme boundary, velars and uvulars are voiceless in the word-final position and voiced in the stem-final position, when followed by a vowel-initial suffix (voicing restriction). The results from elicitation-based production experiments with six native Kazakh speakers reveal that the place restriction is not productive from real words to nonce words but the voicing restriction is. The data suggests a derived-environment effect where the resulting voicing process is conditioned morphologically. A theoretical analysis within Optimality Theory captures the voicing pattern using an indexed-markedness constraint and Local Conjunction.

\section{Introduction}

Most Turkic languages have velar and uvular consonants. These consonant inventories can vary and many of them exhibit restrictions on place of articulation and voicing. Little descriptive work has been done on these types of assimilation processes in Turkic languages (e.g., Comrie 1981; Nevins and Vaux 2004; Pattillo 2013). This paper aims to bridge the gap in the literature by looking at velar and uvular consonants in Kazakh. This language has velar and uvular consonants, but its inventory is asymmetrical.

To illustrate, let me briefly discuss what is already known about velar and uvular consonants in Kazakh. First, velar and uvular consonants are restricted with respect to their neighbouring vowels. Velars appear in words containing front vowels and uvulars appear in words containing back vowels, as shown in (1).

(1) Distribution of velar and uvular consonants (after Bekturova and Bekturov 1996)

a. VELAR
i. $\quad k ø z$
ii. jegeu
'eye'
iii. køgildır
'file'

b. UVULAR

i. qaqlaq 'lid'

ii. qasaz 'paper'

iii. salum 'scholar'

Notice that in the above examples, Kazakh contrasts two velar stops but the uvular consonants are asymmetrical; the voiceless uvular [q] is a stop and the voiced uvular [6] is a fricative (Kara 2002; Mukan 2012; Suleimnenova 2015; Muhamedowa 2016). Second, voiced and voiceless consonants alternate with one another at the morpheme boundary depending on their position in the word. Voiceless consonants 
$[\mathrm{k} / \mathrm{q}]$ appear word-finally while voiced consonants $[\mathrm{g} / \mathrm{s}]$ appear intervocalically with a following vowelinitial suffix, as shown in (2). ${ }^{1}$

(2) Distribution of voiceless/voiced velar and uvular consonants (after Bekturova and Bekturov 1996, Muhamedowa 2016)

a. VELAR

i. VOICELESS: kywælik 'identity card'

ii. VOICED: kywælıgım 'my identity card'

b. UVULAR

i. VOICELESS: qabaq 'brow'

ii. VOICED: qabawu 'his brow'

Notice in the above examples that velar consonants do not alternate in manner, but uvular consonants do; the voiceless uvular [q] appears word-finally as a stop and the voiced uvular [в] appears stem-finally with a following vowel-initial suffix (Kara 2002). Third, there is a fifth dorsal consonant [x] which occurs in loanwords, which can vary freely with [q] ([xat] [qat] 'letter') (Bekturova and Bekturov 1996; Kara 2002; Muhamedowa 2016; Vajda 1994). The distribution and the alternation of [x] have not been described.

The existing descriptions contain rather limited amounts of data, which does not allow generalisations to be drawn about the full distribution of dorsal consonants. Many questions remain unanswered. Are the velar and uvular consonants contrastive intervocalically? What happens to [x]: does it alternate with [q], [g] or [в]? Is the restriction on velars next to front vowels and uvulars next to back vowels productive? Does "next to" the vowel mean before, after, or either? Finally, how do we account for the distribution of velars and uvular consonants theoretically?

To answer these questions, I conducted three elicitation-based production experiments with six native Kazakh speakers. The results revealed the following. In real words, participants produced the target velar and uvular consonants. Velar consonants were produced in words constraining front vowels and uvular consonants were produced in words containing back vowels. There was a voicing alternation in the stem-final position whereby voiceless velar and uvular consonants were produced word-finally and voiced velar and uvular consonants were produced intervocalically. The first generalisation found in real words was not extended to nonce words: the velar and uvular consonants appear unrestricted in stems beside front and back vowels. However, the second generalisation was found to be productive: word-final voiced targets were devoiced and stem-final voiceless targets were voiced intervocalically.

In the theoretical analysis, I focus on the word-final and the stem-final position as opposed to the stem-internal positions. The data suggests that the voicing alternation can be explained as a morphologically-derived environment effect (Burzio 2011; Hall 2006; Kula 2008). I offer an analysis within Optimality Theory (Prince and Smolensky 1993/2004; Kager 2004; McCarthy 2008) using an indexed-markedness constraint (à la Pater 2007) and Local Conjunction (Itô and Mester 2003; Kager 2004; Smolensky 2006; Crowhurst 2011) to capture the pattern.

The paper is structured as follows: Section 2 discusses the background; Section 3 summarises the results from the elicitations; Section 4 offers some discussions points regarding the results; Section 5 provides an analysis within Optimality Theory focusing on the word-final and the stem-final dorsal consonants; and Section 6 briefly concludes.

${ }^{1}$ Final devoicing and intervocalic voicing does not occur exclusively to dorsal consonants. Voiceless and voiced pairs $[\mathrm{p} / \mathrm{b}]$ and $[\mathrm{t} / \mathrm{d}]$ can also replace one another at the morpheme boundary depending on their position in the word. 


\section{Background}

This section provides a more detailed overview of what is already know about velar and uvular consonants in Kazakh. This consonant inventory is asymmetrical. The place restriction on consonants $/ \mathrm{k} /$ and $/ \mathrm{g} /$ exhibit velar and uvular variants that interact with the neighbouring vowels. Native Kazakh words exhibit vowel harmony so velars appear in words containing front vowels and uvulars appear in words containing back vowels. The voicing restriction depends on whether the velar and uvular consonants appear in the word-final position or the stem-final position with a following vowel-initial suffix. Voiceless velar and uvular consonants appear word-finally and voiced velar and uvular consonants appear stem-finally intervocalically. Nothing is known about what happens to the fifth velar consonant $[\mathrm{x}]$ found in loanwords so it is unclear whether this segment exhibits any place or voicing restrictions.

This section is organised as follows. Section 2.1 discusses the velar and uvular consonant inventory, Section 2.2 discusses the place restriction and Section 2.3 discusses the voicing restriction.

\subsection{Velar and uvular consonant inventory}

Kazakh has an inventory of 5 velar and uvular consonants. The inventory is shown in (3).

(3) Kazakh velar and uvular consonants ${ }^{2}$

\begin{tabular}{|l|c|c|c|c|}
\hline & \multicolumn{2}{|c|}{ VELAR } & \multicolumn{2}{c|}{ UVULAR } \\
\hline STOPS & $\mathrm{k}$ & $\mathrm{g}$ & $\mathrm{q}$ & \\
\hline FRICATIVES & $\mathrm{x}$ & & & $\mathrm{b}$ \\
\hline
\end{tabular}

Notice that the above inventory is asymmetrical. There is an imbalanced number of velar and uvular consonants. There is no voiced alternant for the velar fricative and uvular stop, as well as no voiceless alternant for the uvular fricative. There is a disparity in [k] alternating with [q] while maintaining voicing and manner of articulation, but [g] alternating with [5] while maintaining voicing but not manner of articulation. There is also a disparity in the velars $[\mathrm{k}]$ alternating with $[\mathrm{g}]$ in voicing while maintaining manner of articulation, but [q] alternating with [в] in voicing without preserving manner or articulation. Finally, the velar [x] found in loanwords can alternate freely with the uvular [q] (e.g. [xat] [qat] 'letter' (Bekturova and Bekturov 1996)), whereby the alternation differs in both place and manner of articulation.

\subsection{Place restriction}

Velar and uvular consonants are restricted in the place of articulation depending on neighbouring vowels. Like in many Turkic languages, vowel harmony is a key feature in native Kazakh words, whereby all vowels are either front or back. This affects whether a dorsal consonant within a word is velar or uvular. Each word usually contains only front vowels or back vowels, as shown in (4).

\footnotetext{
${ }^{2}$ Voiceless sounds are on the left side of the column and voiced sounds are on the right side of the column.
} 
(4) Examples of front and back harmony within a word (after Bekturova and Bekturov 1996; Bowman and Lokshin 2014)

a. FRONT

$\begin{array}{lll}\text { i. } \quad \text { emirfek } & \text { 'gristle' } \\ \text { ii. } \quad \text { kyrek } & \text { 'shovel' } \\ \text { iii. } & \text { esIk } & \text { 'door' } \\ \text { iv. } & \text { kepemet } & \text { 'amazing', } \\ \text { v. tyngI } & \text { 'nightime' } \\ \text { vi. } & \text { søgis } & \text { 'pasture' } \\ \text { vii. } & \text { Sigit } & \text { 'young' }\end{array}$

b. BACK

$\begin{array}{lll}\text { i. } & \text { zomurtqa } & \text { 'egg' } \\ \text { ii. } & \text { sarumsaq } & \text { 'garlic' } \\ \text { iii. } & \text { qalam } & \text { 'pen' } \\ \text { iv. } & \text { qasaz } & \text { 'paper' } \\ \text { v. basan } & \text { 'column' } \\ \text { vi. } & \text { ralum } & \text { 'scholar' } \\ \text { vii. } & \text { balıa } & \text { 'hammer' }\end{array}$

Notice in the above examples that velar consonants appear in front vowel environments and uvular consonants appear in back vowel environments (Muhamedowa 2016). Vowel harmony and the distribution of velar and uvular consonants also play a role morphologically. Suffixes also show front and back alternations that harmonise with the stem and assimilate in voicing to the preceding consonant in clusters, as shows in (5) using the dative marker. ${ }^{3}$

(5) Harmony with the dative suffix $-G A$

a. FRONT

i. ROOT
a. keme 'ship'
b. Selek 'bucket'
c. sæbiz 'carrot'

ii. ROOT-DAT
a. keme-ge 'to the ship'
b. Selek-ke 'to the bucket'
c. sæbiz-ge 'to the carrot'

b. BACK

i. ROOT
a. awa 'air'
b. bas 'head'
c. tuz 'salt'

ii. ROOT-DAT
a. awa-ra 'to the air'
b. bas-qa 'to the head'
c. tuz-ra 'to the salt'

\footnotetext{
${ }^{3}$ The realisation of the dative suffix -GA is dependent on the frontness of the preceding vowel of the word $(\mathrm{A}=\mathrm{e}[-\mathrm{back}], \mathrm{a}[+\mathrm{back}])$ and whether the stem ends in a voiceless consonant $(\mathrm{G}=\mathrm{k}$ [-back], $\mathrm{q}$ [+back]), or in a voiced consonant or a vowel $(\mathrm{G}=\mathrm{g}[-$ back $]$, в $[+$ back $])$.
} 
Notice in the above examples that the realisation of the dative maker - $G A$ varies depending on the stem to which it attaches. In terms of the vowels, if the stem vowel is front, the suffix vowel will be the front [e] and if the stem vowel is back, the suffix vowel will be the back [a]. In terms of the velar and uvular consonants, if the stem vowel is front, the suffix consonant will be velar $[\mathrm{k} / \mathrm{g}]$, and if the stem vowel is back, the suffix consonant will be uvular $[\mathrm{q} / \mathrm{s}]$. Also, if the stem ends with a voiceless consonant, the suffix consonant will be voiceless $[\mathrm{k} / \mathrm{q}]$, and if the stem ends in a voiced consonant or a vowel, the suffix consonant will be voiced $[\mathrm{g} / \mathrm{s}]$.

Loanwords and words containing [x] are exceptions to vowel harmony and can remain nonharmonic, as show in (6) (Kara 2002; Muhamedowa 2016).

(6) Loanwords in Kazakh (after Batayeva 2013; Kara 2002)

$\begin{array}{llll}\text { a. kitap } & \text { 'book' } & \text { (Arabic) } \\ \text { b. kæmzol } & \text { 'sort of blouse' } & \text { (Persian) } \\ \text { c. sumkæ } & \text { 'bag' } & \text { (Russian) } \\ \text { d. tarix } & \text { 'history' } & \text { (Arabic) }\end{array}$

Notice in the above examples that these words do not contain only front vowels or back vowels.

\subsection{Voicing restriction}

Velar and uvular consonants are restricted in voicing depending on what position the stem-final consonant appears in a word. As in many Turkic languages, the voicing alternation is also a key feature at the morpheme boundary of Kazakh words. This affects whether the dorsal consonant appears as voiced or voiceless.

This paper examines two phonological phenomena: word-final devoicing and stem-final intervocalic voicing when followed by a vowel initial suffix, as shown in (7).

(7) Examples of velar alternations (after Bekturova and Bekturov 1996)

a. VELAR

i. WORD-FINAL: kywælik 'identity card'

ii. INTERVOCALIC: kywælıgIm 'my identity card'

b. UVULAR

i. WORD-FINAL: qasuq 'spoon'

ii. INTERVOCALIC: qasurum 'his/her spoon'

Notice in the above examples that the voiceless velar and uvular consonants appear in the word-final position and the voiced velar and uvular consonants appear intervocalically with a following vowel-initial suffix (Kara 2002). Voiceless and voiced pairs or velar and uvular consonants alternate with one another but it is ambiguous whether it is word-final devoicing or intervocalic voicing. Nothing is known about what happens to $[\mathrm{x}]$.

Due to insufficient explanations in the literature regarding the properties of Kazakh velar and uvular consonants, I conducted three elicitation-based experiments with 6 native Kazakh speakers. The following section discusses the results from those elicitations.

\section{Results}

This section discusses the results from the elicitations. I present the results going through the place restriction and the voicing restriction. There are several main findings. First, the pattern whereby velar consonants are produced in front vowel environments and uvular consonants are produced in back vowel environments was not extended to nonce words. All five dorsal consonants were unrestricted in the wordinitial, word-medial, and word-final positions in nonce words containing front or back vowels. Second, 
the pattern whereby voiceless velar and uvular consonants appear word-finally and voiced velar and uvular consonants appear intervocalically with a following vowel-initial suffix was extended to nonce words. Target voiced velar and uvular consonants were devoiced in the word-final position and target voiceless velar and uvular consonants were voiced intervocalically. Third, the voiceless velar fricative [x] alternated with the voiced uvular fricative $[\mathrm{b}]$ in the word-final and stem-final positions.

This section is organised as follows. Section 3.1 presents the place restriction results and Section 3.2 presents the voicing restriction results.

\subsection{Place restriction}

The place restriction observed in real words was not extended to nonce words. In real words, participants produced target velar consonants in front vowel environments and target uvular consonants in back vowel environments, as shown in (8).

(8) Velar and Uvular Consonants
a. VELAR
i. [købelek] 'butterfly'
ii. [øttegI] 'oxygen'
b. UVULAR
$\begin{array}{ll}\text { i. } & \text { [qarbuz }] \\ \text { ii. } & \text { 'wasban] 'watermelon' }\end{array}$

Notice in the above examples that, indeed, velar consonants do appear with front vowels and uvular consonants do appear with back vowels However, loanwords were exceptions to this pattern because they can remain nonharmonic, as shown in (9).

(9) Velar and Uvular Consonants in Loanwords
a. VELAR
i. [gazet] 'newspaper'
ii. [magnitofon] 'tape recorder'
b. UVULAR

i. [qupijæ] 'secret'

Notice in the above examples that the Kazakh loanwords do not follow vowel harmony. Also, all participants produced the target $/ \mathrm{x} /$ as a voiceless velar fricative with no indication that it freely alternated with $[\mathrm{q}]$.

In nonce words, we expected participants to produce velar consonants in front vowel nonce words even if the letter corresponded to a uvular consonant, and the reverse situation for uvular consonants in written stimuli. However, this did not turn out to be the case. Participants produced the target velar and uvular consonants regardless of the vowel. This included the fifth dorsal consonant [x]. All five consonants were produced invariably, regardless of whether a front or back vowel appeared in the nonce words. Thus, the results suggest that nonce words patterned with loanwords, where the distribution of dorsal consonants is not limited in its place of articulation. This shows that the place restriction does not seem to be productive.

\subsection{Voicing restriction}

The voicing restriction observed in real words was extended to nonce words. In real words, participants produced voiceless velar consonants in front vowel environments and voiceless uvular consonants in back vowel environments in the word final position, as shown in (10). 
(10) Dorsal consonants in word final position
a. VELAR:
[købelek]
'butterfly'
b. UVULAR:
[qasuiq]
'spoon'

Notice in the above examples that the word-final segment is voiceless whether it be a velar or a uvular consonant. Participants also produced voiced velar consonants in front vowel environments and voiced uvular consonants in back vowel environments intervocalically with a following vowel-initial suffix, as shown in (11).

(11) Dorsal consonants in stem-final position

a. VELAR

i. [jetık]

boot.SG

'boot'

ii. [marat -tur jetrg -I $]$

Marat -GEN boot -POSS

b. UVULAR

'Marat's boot'
i. [quzbaldaq]
poppy.SG
'poppy'

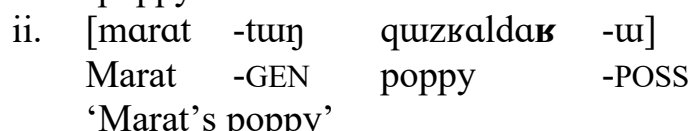

Notice in the above examples that the stem-final segment is voiced intervocalically with a following vowel-initial suffix. Also, intervocalic voicing is extended to the stem-final [x], as shown in (12).

(12) $/ \mathrm{x} /$ in stem-final position
a. [tarix]
history.SG
'history'
b. [qazaqstan respuwblika -su -nuy taris -I]
Kazakhstan republic -POSS -GEN history -POSS
'Republic of Kazakhstan's history'

Notice in the above examples that $/ \mathrm{x} /$ voiced to [ь] intervocalically.

In nonce words, we expected participants to devoice voiced targets word-finally. We anticipated participants to neutralise voiced velar $/ \mathrm{g} /$ to voiceless [k] and the voiced uvular [6] to voiceless [q]. Four of the six participants devoiced all voiced targets in the word-final position while the other two preserved the word-final voiced consonant when reading from written stimuli. However, all participants produced word-final voiced targets as devoicing from auditory stimuli. This included the fifth dorsal consonant $[\mathrm{x}]$, which was produced faithfully (since it is voiceless already). We also expected participants to voice stemfinal voiceless velar and uvular consonants intervocalically with a following vowel-initial suffix. All participants produced the stem-final target voiceless velar and uvular consonants as voiced intervocalically.

The surprising results concerned the velar and uvular fricatives $[\mathrm{x}]$ and $[\mathrm{b}]$. First, the voiced velar $/ \mathrm{g} /$ neutralised to $[\mathrm{k}]$ but the voiced uvular [b] did not neutralise to [q], as expected, but partially neutralised to $[\chi]$ when using written stimuli but to $[\mathrm{x}]$ when using auditory stimuli. The manner of articulation was maintained, even when it resulted in an illicit segment. Second, the stem-final /x/ voiced to [в] intervocalically when followed by a vowel-initial suffix. This matches the real word production. Thus, the 
results suggest that nonce words patterned with real words where the distribution of stem-final velar and uvular consonants is limited in its voicing pattern. This shows that the voicing restriction seems to be productive.

\section{Discussion}

This section is a discussion of the results that were explained in the previous section. The results found that the place restriction was not productive but the voicing restriction concerning their extension from real words to nonce words. The voicing restriction contributed the most to the description of Kazakh and provides the greater basis for some interesting discussion points.

First, we determined that the place restriction found in real words was not extended to nonce words. Real words show velar consonants appearing in front vowel environments, and uvular consonants appearing in back vowels environment, but this strict pattern was not found in nonce words. There are several possible explanations for this. It could be that the restriction on the place of articulation is no longer productive. The pattern observed in native words would not be extended to new words. It could be that participants treated nonce words as loanwords. Since the place restriction is not found in Kazakh loanwords, participants would not neutralise place of articulation in loanwords and would instead pronounce them faithfully. We know that loanwords are often exceptional cross-linguistically (see Itô and Mester 1999, 2001 and Kang 2011 for an overview) so this is not surprising. It could be that the place neutralisation was not obtained due to the task effect. When reading, participants fail to neutralise, thus neutralisation could be described as incomplete (e.g., Slowiaczek and Dinnsen 1985; Charles-Luce and Dinnsen 1987; Warner et al. 2004; Dmitrieva et al. 2010; Kharlamov 2012, 2014; Roettger et al. 2014 and many others).

Second, the voicing facts are more complex. We have also determined that the voicing restriction found in real words was extended to nonce words. For word-final devoicing, recall that two of the participants invariably produced voiced segments in the word-final position faithfully. Also, all participants invariably neutralised $[\mathrm{s}]$ with $[\mathrm{x}]$, instead of the expected $[\mathrm{q}]$, in the word-final position. Even though participants were asked to treat nonce words as if they were real words, it is possible that participants treated nonce words as loanwords. In many languages, loanwords may allow less restrictive phonotactic requirements than for native words, This phenomenon can be modelled using a co-phonology approach (Orgun 1996; Inkelas et al. 1997; Antila 2002; Inkelas and Zoll 2007) or indexed constraints (Itô and Mester 1999, 2001; Pater 2007; Flack 2007). The co-phonology approach captures the diversity between native and loanword phonology by associating a lexical or morphological class with a different phonological grammar. The indexed constraint approach captures the diversity under a single constraint ranking for the entire language but a constraint within the ranking is indexed to an individual morpheme.

It is also possible that neutralisation was incomplete. The reading task using written stimuli confirmed that incomplete neutralisation could stem from the influence orthography has on written speech. If spelling suggests a difference, participants may make a distinction during careful speech. This was demonstrated by no devoicing in the word-final position and the participants' ability to produce a velar beside a back vowel and a uvular beside a front vowel.

For stem-final intervocalic voicing with a following vowel-initial suffix, the voicing alternation occurs at the local domain of the suffix and does not occur in the identical environment found wordinternally, as shown in (13). 
(13) Intervocalic velar and uvular consonants within a word and at a morpheme boundary

a. $\quad c v C v$

$\mathrm{k}: . \quad \mathrm{s} \varnothing \mathrm{k} \varnothing$

q: zoqu

g: laga

в: bІиі

$\mathrm{x}: \quad \mathrm{s} \varnothing \mathbf{x} \varnothing$

b. $\quad \operatorname{cvccv} \boldsymbol{C}-\boldsymbol{v}$

$\begin{array}{llll}\mathrm{k}: & \text { zobsug } & -\mathrm{a} & -\mathrm{du} \\ \mathrm{q}: & \text { søbzør } & -\mathrm{e} & -\mathrm{dI} \\ \mathrm{g}: & \text { libsig } & -\mathrm{e} & -\mathrm{dI} \\ \mathrm{s:} & \text { bølsør } & -\mathrm{e} & -\mathrm{dI} \\ \mathrm{x}: & \text { zalbar } & -\mathrm{a} & -\mathrm{du} \\ & \text { verb } & -\mathrm{CONV} & -\mathrm{PST} \\ & \text { 'S/he [verb]s (usually)' or 'S/he will [verb]' }\end{array}$

The morphological boundary constitutes a specific environment for a phonological phenomenon. This can be characterised as a derived-environment effect whereby the voicing alternation is limited to the morpheme boundary and thus the phonological process is conditioned morphologically (Burzio 2011; Hall 2006; Kula 2008).

The indexed constraint theory of lexical exceptions offers the opportunity to propose a morphemespecific markedness constraint. These types of constraints are limited to a specific set of suffixes and apply to entire outputs in which the indexed constraints occur. Pater (2007) discusses how a phonological process applies when the conditioned environment contains a portion of an affix in a morphologicallyderived environment. The scope is limited to the string of segments that contains some portion of the morpheme.

The voicing restriction contributed the most to the description of Kazakh since this phonological process is productive across real and nonce words. The place restriction was not productive and will not be discussed further since this phenomenon has been previously explored (see Bekturova and Bekturov 1996; Kara 2002; Batayeva 2013; Muhamedowa 2016). The following section will provide an Optimality Theory analysis that accounts for final devoicing and intervocalic voicing.

\section{Analysis}

This section provides an analysis within Optimality Theory (OT) (Prince and Smolensky 1993/2004; Kager 2004; McCarthy 2008) that accounts for both final devoicing and intervocalic voicing of the velar and uvular consonants. To capture the voicing pattern, standard featural assumptions are used whereby all segments are fully specified for their voicing, place and manner. The feature [ \pm voice] differentiates between voiced ([g] and $[\mathrm{b}]$ ) and voiceless ([k], [q] and $[\mathrm{x}]$ ) segments, the feature $[ \pm$ high $]$ differentiates between velars $([\mathrm{k}],[\mathrm{g}]$ and $[\mathrm{x}])$ and uvular ([q] and $[\mathrm{b}])$ segments and the feature $[ \pm$ continuant] differentiates between fricative ([x] and $[\mathrm{b}])$ and stop ([k], $[\mathrm{q}]$ and $[\mathrm{g}])$ segments. ${ }^{4}$ A combination of an indexed-markedness constraint (see Pater 2007) and Local Conjunction (see Itô and Mester 2003; Smolensky 2006; Crowhurst 2011) are used to account for the voicing patterns.

The analysis is organised as follows. Section 5.1 presents word-final devoicing and Section 5.2 presents intervocalic voicing.

\footnotetext{
${ }^{4}$ See Spencer (1996) and Odden (2005) for a description of the feature [ \pm high] used to distinguish between velars and uvulars. Kazakh has systematic contrast between velars [+high] and uvulars [-high] in front and back environments respectively. In Klamath, Halle (1995) categorises velar and uvular stops in Klamath using the feature [ \pm high].
} 


\subsection{Final devoicing}

This section presents the analysis for word-final devoicing. The results show that the voiced velar and uvular consonants $[\mathrm{g}]$ and $[\mathrm{b}]$ neutralise to $[\mathrm{k}]$ and $[\mathrm{x}]$, respectively, in the word-final position. The underlying distinctions are lost on the surface form for $[\mathrm{g}]$ and $[\mathrm{c}]$ word-finally.

Since voiced velar and uvular consonants invariable devoice in the word-final position, I employ the word-final devoicing constraint, as shown in (14).

(14) FINDEV

No voiced obstruents in word-final position.

This constraint prevents a voiced segment from surfacing in the word-final position.

Since voicing occurs over being faithful to [voice], FINDEV is ranked higher than the faithfulness constraint in (15) for the voicing feature.

(15) IDENT(voi)

The input and output must have the same value for the feature [voice].

This constraint prevents a change in the VOICE specification of a segment from input to output.

Let us first consider $/ \mathrm{g} /$ neutralising to $[\mathrm{k}]$ in the word-final position. Voicing changes while maintaining place and manner of articulation. Consider the tableau in (16). Candidate (b) fatally violates the top-ranked constraint FINDEV, which the winning candidate (a) does not.

(16) Final devoicing of a voiced velar consonant

\begin{tabular}{||rl||c|c||}
\hline & /libsig/ & FINDEV & IDENT(voi) \\
\hline \hline a. & libsik & & $*$ \\
\hline b. & libsig & $* !$ & \\
\hline
\end{tabular}

Now consider that /в/ devoices to [x], and not $[\chi]$ which is not a possible segment, in the word-final position. This involves a more complex situation. One expects the voiced uvular [b] to neutralise to the voiceless uvular counterpart $[\mathrm{q}]$; however, this is not the case. To account for $[\mathrm{b}]$ changing place of articulation and preserving manner of articulation to $[\mathrm{x}]$ in the word-final position, instead of changing manner of articulation and preserving place of articulation to [q], additional constraints are required. I employed two lower ranked faithfulness constraints whereby maintaining manner of articulation in (17) is ranked higher than maintaining place of articulation in (18).

\section{(17) IDENT(cont)}

The input and output must have the same value for the feature [cont].

This constraint prevents a change in the [continuant] specification of a segment from input to output.

(18) $\operatorname{IDENT}($ hi)

The input and output must have the same value for the feature [hi].

This constraint prevents a change in the continuant [high] of a segment from input to output.

IDENT constraints fall under McCarthy and Prince's (1995) correspondence constraints whereby a constraint checks that input and output segments agree in feature specification. Since manner is maintained of articulation is maintained of place of articulation when [ $\mathrm{b}$ ] neutralised to [x], instead of to [q], in the word-final position, IDENT(cont) must be ranked higher than IDENT(hi). I also employ a higher ranked markedness constraint ${ }^{*} \chi$ that ensures the voiceless uvular fricative does not surface. This is an 
instance of Structure Preservation (e.g., Kiparsky 1985) whereby a phonological rule will not introduce a novel sound that is not part of the phoneme inventory. The segment $[\chi]$ is not found within the Kazakh consonant inventory and should not be a possible output under any circumstance. We also know that FINDEV must rank above IDENT(voi) and IDENT(cont) must be ranked above IDENT(hi).

Consider the tableau in (19) for / $\mathrm{b} /$ neutralising to [x] word-finally. Voicing and place of articulation change while maintaining manner of articulation. Candidate (a) and (b) fatally violate the top-ranked constraints * $\chi$ and FINDEV, respectively. Both candidate (c) and (d) violate IDENT(voi) but candidate (d) fatally violates IDENT(cont), which candidate (c) does not.

(19) Final devoicing of a voiced uvular consonant

\begin{tabular}{|rl|c:c|c|c|c|}
\hline & $/$ libsib $/$ & ${ }^{*} \chi$ & FINDEV & IDENT(voi) & IDENT(cont) & IDENT(hi) \\
\hline \hline a. & $\operatorname{libsi} \chi$ & $* !$ & & $*$ & & \\
\hline b. & libsib & & $* !$ & & & \\
\hline c. & $\operatorname{libsix}$ & & & $*$ & & $*$ \\
\hline d. & libsiq & & & $*$ & $* !$ & \\
\hline
\end{tabular}

\subsection{Intervocalic voicing}

This section presents the analysis for intervocalic voicing. The results show that the voiceless velar $/ \mathrm{k} /$ voices to [g] and both the voiceless uvular stop /q/ and the voiceless velar fricative /x/ voice to [в].

Since voiceless velars and uvulars voice at the stem-final boundary when followed by a vowel-initial suffix, I employ the indexed-markedness constraint in (20) which does not allow morpheme specific voiceless segments to appear intervocalically.

(20) $* \mathrm{VTV}_{\text {SUFFIX }}$

No voiceless obstruents intervocalically in the suffix.

This constraint prevents a morpheme-specific string where a voiceless segment is not allowed to surface intervocalically in the output and will apply when any part of the string falls within the suffix. In other words, a suffix vowel will affect the stem consonant but is blocked from applying in the identical steminternal environment. The voicing pattern is captured using one constraint ranking while being able to account for the morphologically-conditioned phonology. Since voiceless velar and uvular consonants voice intervocalically at the morpheme boundary, ${ }^{*} \mathrm{VTV}_{\text {SuFrI }}$ must be ranked higher than IDENT(voi). A voicing change is favoured over being faithful to [voice].

Let's first consider / $\mathrm{k} /$ voicing to [g] intervocalically when followed by a vowel-initial suffix. Voicing changes while maintaining place of articulation and manner of articulation. Consider the tableau in (21). Candidates (a), (c) and (d) fatally violate the higher ranked constraint *VTV $V_{\text {sufrix. }}$ Recall that this constraint applies to the stem-final consonant because of the locality effect (see Pater 2007). Both candidates (b) and (e) violate IDENT(voi) but candidate (e) fatally violates IDENT(cont), which candidate (b) does not.

(21) Intervocalic voicing of a velar stop

\begin{tabular}{|rl||c|c:c|c||}
\hline & /libsik-I & $*$ VTV $_{\text {SUFFI }}$ & IDENT(voi) & IDENT(cont) & IDENT(hi) \\
\hline \hline$L_{F}$ a. & libsik-I & $* !$ & & & \\
\hline b. & libsig-I & & $*$ & & \\
\hline c. & libsix-I & $* !$ & & $*$ & \\
\hline d. & libsiq-I & $* !$ & & $* !$ & $*$ \\
\hline e. & libsib-I & & $*$ & & $*$ \\
\hline
\end{tabular}


Let's now consider / $\mathrm{x} /$ voicing to [в] intervocalically when followed by a vowel-initial suffix. Voicing and place of articulation change while maintaining manner of articulation. Consider the tableau in (22). Candidates (a), (b) and (e) fatally violate the top-ranked constraint $* \mathrm{VTV}_{\text {Sufrix. }}$ Both candidates (c) and (d) violate IDENT(voi) but candidate (c) fatally violates IDENT(cont), which candidate (d) does not.

(22) Intervocalic voicing of $/ \mathrm{x} /$

\begin{tabular}{|c|c|c|c|c|c|}
\hline & /1Ibsix-I/ & $* \mathrm{VTV}_{\text {SUFFIX }}$ & IDENT(voi) & IDENT(cont) & IDENT(hi) \\
\hline a. & 1IbsIX-I & $* !$ & & & \\
\hline b. & libsık-I & $* !$ & & $*$ & \\
\hline c. & libsig-I & & $*$ & $* !$ & \\
\hline$C \mathrm{~d}$. & libsIK-I & & $*$ & & $*$ \\
\hline e. & libsiq-I & $* !$ & & $*$ & $*$ \\
\hline
\end{tabular}

Finally, let's consider /q/ voicing to [в] intervocalically when followed by a vowel-initial suffix. Voicing and manner of articulation change while maintaining place of articulation. An additional constraint is required to account for both $/ \mathrm{q} /$ and $/ \mathrm{x} /$ voicing to [r]. In the $/ \mathrm{x} /$ alternation, the manner of articulation is respected but not place of articulation; In the /q/ alternation, the place of articulation is respected but not manner of articulation. At this point, the current constraint ranking favours /q/ alternating with $[\mathrm{g}]$ over $[\mathrm{B}]$

To rule out unattested alternations, I employ a locally-conjoined constraint. This type of constraint creates a single composite constraint by conjoining two constraints. Itô and Mester (2003) and Smolensky (2006) assume that Universal Grammar makes a combinatorial operation "\&" available to individual languages. These languages may choose to activate " $\&$ " to derive a complex constraint on a languagespecific basis. Smolensky (2006: 43) defines Local Conjunction as follows in (23).

(23) Local Conjunction within a domain D (Smolensky 2006: 43)

$* A \&_{D} * B$ is violated if and only if a violation of $* A$ and a (distinct) violation of $* B$ occur within a single domain of type D.

A constraint conjunction expands the expressive power of Optimality Theory. Conjoined constraints also increase the available set of constraints and improve the precision of the evaluation process of possible candidates (Crowhurst 2011). Locally-conjoined constraints will incur a violation if and only if both members of the complex constraint are violated within a specified domain (Kager 2004). Therefore, I employ the composite constraint in (24), which requires place of articulation to be maintained and, at the same time, disfavours a morpheme-specific intervocalic velar consonant.

(24) IDENT(hi)\&*VC $\left[+\right.$ hi] $\mathrm{V}_{\text {suFfIX }}$

This constraint is violated if and only if the input and the output doesn't have the same value for [hi] and a velar obstruent appears intervocalically in the local domain of the suffix.

This ensures that place of articulation is maintained from input to output while intervocalic velars are not permitted in the output. It is possible for candidates to violate one part or the other but they cannot violate both parts simultaneously. IDENT(hi) \&*VC $\mathrm{VC}_{[+ \text {hi] }} \mathrm{V}_{\text {SUFFIX }}$ must be ranked below $* \mathrm{VTV}_{\text {Suffix }}$ because intervocalic voicing at the morpheme boundary continues to be favoured. IDENT(hi)\&*VC $\mathrm{V}_{[+\mathrm{hi}]} \mathrm{V}_{\text {SUFFIX }}$ must be ranked above IDENT(cont) because simultaneously faithfulness to place and preventing an intervocalic velar at the morpheme boundary is favoured over being faithful to manner. This rules out [g] surfacing over [в]. Ultimately, it is okay to change place as long as it does not result in a velar intervocalically.

Now consider the tableau in (25). Candidates (a), (c) and (e) fatally violate the top-ranked constraint

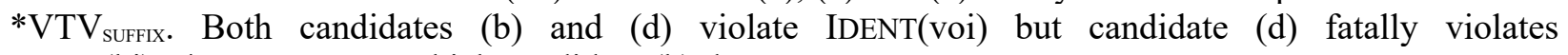
IDENT(hi)\&* $\mathrm{VC}_{[+\mathrm{hi}]} \mathrm{V}_{\text {SUFFIX }}$, which candidate (b) does not. 
(25) Intervocalic Voicing of Uvular Stops

\begin{tabular}{|c|c|c|c|c|c|c|}
\hline & /libsıq-I/ & $* \mathrm{VTV}_{\text {SUFFIX }}$ & $\begin{array}{l}\text { IDENT } \\
\text { (voi) }\end{array}$ & $\begin{array}{l}\text { IDENT(hi)\& } \\
* \mathrm{VC}_{[+\mathrm{hi}]} \mathrm{V}_{\text {SUFFIX }}\end{array}$ & $\begin{array}{l}\text { IDENT } \\
\text { (cont) }\end{array}$ & $\begin{array}{l}\text { IDENT } \\
\text { (hi) }\end{array}$ \\
\hline$\Leftrightarrow a$. & 1Ibsiq-I & $* !$ & & & & \\
\hline $\mathrm{b}$. & 1IbsIB-I & & $*$ & & $*$ & \\
\hline c. & libsık-I & $* !$ & & $*$ & & * \\
\hline d. & libsig-I & & $*$ & $* !$ & & $*$ \\
\hline e. & libsIX-I & $* !$ & & $*$ & $*$ & $*$ \\
\hline
\end{tabular}

To summarise, the change in voicing may result in illicit consonants in Kazakh, whereby the next best option is chosen by changing place of articulation, rather than manner of articulations. This is seen by $/ \mathrm{x} /$ voicing to $[\mathrm{b}]$, instead of voicing to [g], while $/ \mathrm{s} /$ devoices to [x], instead of devoicing to [q]. Under the constraint ranking IDENT(voi), IDENT(cont) $>>\operatorname{IDENT(hi),~one~would~expect~/q/~to~voice~to~[g],~but~}$ instead it voices to $[\mathrm{b}]$ unexpectedly. The local conjunction that created the single composite constraint IDENT(hi)\&* $\mathrm{VC}_{[+ \text {hi] }} \mathrm{V}_{\text {SufFIx }}$ prevents the change into an intervocalic $[\mathrm{g}]$ when followed by a vowel-initial suffix.

The constraint ranking in the above analysis is not always obvious and is somewhat complex. The relationship between constraints can be visualised in the following diagram in (26).

(26) The constraints

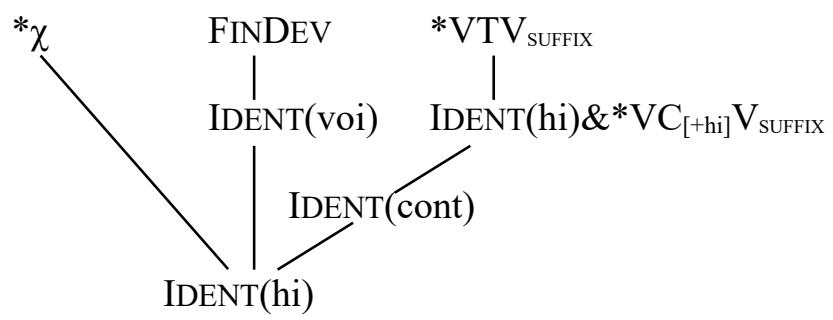

The analysis above accounted for word-final devoicing and intervocalic voicing when followed by a vowel-initial suffix. The voicing pattern of velar and uvular consonants in Kazakh suggests a derivedenvironment effect (Burzio 2011; Hall 2006; Kula 2008) and is captured within Optimality Theory (Prince and Smolensky 1993/2004; Kager 2004; McCarthy 2008) using an indexed-marked constraint to account for the morphologically-conditioned phonological process (Pater 2007) and a Local Conjunction constraint (Itô and Mester 2003; Kager 2004; Smolensky 2006; Crowhurst 2011) to account for [q] and $[\mathrm{x}]$ voicing to $[\mathrm{b}]$.

\section{Conclusion}

This paper looked at the asymmetrical inventory of velar and uvular consonants in Kazakh. Existing descriptions contain limited amounts of data, which made it difficult to draw any generalisations regarding the full distribution of velar and uvular consonants in Kazakh. The aim of this research was to fill the gap in the literature by conducting elicitation-based experiments using real and nonce words.

The results provided several generalisations. In real words, participants produced target velar consonants in front vowel environments and target uvular consonants in back vowel environments. However, in nonce words, the velar and uvular consonants were unrestricted in front and back vowel environments. While the place restriction was not productive and did not extend from real words to nonce words, the voicing restriction was productive. Participants produced word-final voiced targets as devoiced word-finally and stem-final voiceless targets as voiced when followed by a vowel-initial suffix.

A better understanding of Kazakh velar and uvular consonants was achieved from the elicitationbased production experiments, which increased the amount of data on Kazakh. The voicing patterns, 
word-final devoicing and intervocalic voicing, contributed the most to the description since the voicing alternations were productive across real and nonce words. Focusing on these two phenomena, the data suggests a derived-environment effect whereby the phonological process is conditioned morphologically. A theoretical analysis of the voicing alternations was captured within Optimality Theory using an indexed-markedness constraint and Local Conjunction. In short, this presents one of the most extensive works done on Kazakh yet.

Acknowledgements. I would like to take this opportunity to briefly thank those who have helped me with this project. First, thank you to Peter Jurgec for being a wonderful supervisor. Second, thank you to Yoonjung Kang and Keren Rice for the helpful suggestions and comments. Third, thank you to my six participants for volunteering to participate in my project. Fourth, thank you to the attendees of the Summer Phonology Forum, Montreal-Ottawa-Toronto Phonology/Phonetics Workshop and the $27^{\text {th }}$ Manchester Phonology Meeting for the invaluable feedback. Finally, thank you to the anonymous copyeditor for catching all my errors, most of which were inexcusable.

\section{References}

Batayeva, Zaure. 2013. Colloquial Kazakh: The complete course for beginners. New York: Routledge. Bekturova, A., and Sh. Bekturov. 1996. Manual of the Kazakh language. Almaty: Rauan.

Bowman, Samuel R., and Benjamin Lokshin. 2013. Idiosyncratically transparent vowels in Kazakh. In Proceedings of the 2013 Annual Meeting on Phonology, ed. John Kingston, Claire Moore-Cantwell, Joe Pater, and Robert Staubs. Oxford: Oxford University Press.

Burzio, Luigi. 2011. Derived environment effects. In Blackwell companion to phonology, ed. Marc van Oostendorp, Colin J. Ewens, Elizabeth Hume, and Keren D. Rice, 2089-2114. Malden, MA: Blackwell Publishing.

Charles-Luce, Jan, and Daniel A. Dinnsen. 1987. A reanalysis of Catalan devoicing. Journal of Phonetics 15(1): 187-190.

Comrie, Bernard. 1981. The languages of the Soviet Union. Cambridge: Cambridge University Press.

Crowhurst, Megan J. 2011. Constraint Conjunction. In Blackwell companion to phonology, ed. Marc van Oostendorp, Colin J. Ewens, Elizabeth Hume and Keren D. Rice, 1-62. Malden, MA: Blackwell Publishing.

Dmitrieva, Olga, Allard Jongman, and Joan Sereno. 2010. Phonological neutralization by native and nonnative speakers: The case of Russian final devoicing. Journal of Phonetics 38(3): 483-492.

Flack, Kathryn. 2007. Templatic morphology and indexed markedness constraints. Linguistic Inquiry 38(4): 749-758.

Hall, Tracy Alan. 2006. Derived environment blocking effects in Optimality Theory. Natural Language and Linguistics Theory 24(3): 803-856.

Halle, Morris. 1995. Feature geometry and feature spreading. Linguistic Inquiry 26(1): 1-46.

Inkelas, Sharon, Orhan Orgun, and Cheryl Zoll. 1997. The implications of lexical exceptions for the nature of grammar. In Derivations and constraints in phonology, ed. Iggy Roca, 393-418. Oxford: Clarendon Press.

Inkelas, Sharon, and Cheryl Zoll. 2007. Is grammar dependence real? A comparison between cophonological and indexed constrain approaches to morphologically conditioned phonology. Linguistics 45(1): 133-172.

Itô, Junko, and Armin Mester. 1999. The phonological lexicon. In The handbook of Japanese linguistics, ed. Natsuko Tsujimura, 62-100. Oxford: Blackwell Publishing.

Itô, Junko, and Armin Mester. 2001. Covert generalizations in Optimality Theory: The role of stratal faithfulness constraints. Studies in Phonetics, Phonology, and Morphology 7(2): 273-299.

Kager, Rene. 2004. Optimality Theory. Cambridge: Cambridge University Press. 
Kang, Yoonjung. 2011. Loanword Phonology. In Blackwell companion to phonology, ed. Marc. van Oostendorp, Colin J. Ewens, Elizabeth Hume and Keren D. Rice, 2258-2282. Malden, MA: Blackwell Publishing.

Kara, Dávid Somfai. 2002. Kazak. Muenchen: Lincom Europe.

Kiparsky, Paul. 1985. Some consequences of lexical phonology. Phonology Yearbook 2: 85-138.

Kula, Nancy C. 2008. Derived environment effects: A representational approach. Lingua 118(9): 13281343.

McCarthy, John J. 2008. Doing Optimality Theory. Malden, MA: Blackwell Publishing.

McCarthy, John J., and Alan Prince. 1995. Faithfulness and reduplicative identity. In University of Massachusetts Occasional Papers 18: Papers in Optimality Theory, ed. Jill Beckman, Laura Walsh Dickey and Susanne Urbanczyk, 249-384. Amherst, MA: University of Massachusetts Graduate Linguistic Student Association.

Muhamedowa, Raihan. 2016. Kazakh: A comprehensive grammar. New York, NY: Routledge.

Nevins, Andrew, and Bert Vaux. 2004. Consonant Harmony in Karaim. In MIT Working Papers in Linguistics 46, ed. Aniko Csirmaz, Youngjoo Lee, and MaryAnn Walter, 175-194. Cambridge: MITWPL.

Odden, David. 2005. Introducing phonology. Cambridge: Cambridge University Press.

Orgun, Orhan. 1996. Sign-based morphology and phonology: With special attention to Optimality Theory. Doctoral dissertation, University of California Berkeley.

Pater, Joe. 2007. The locus of exceptionality: Morpheme-specific phonology as constraint indexation. In University of Massachusetts Occasional Papers in Linguistics 32, ed. L. Bateman, M. O'Keefe, E. Reilly and A. Werle, 259-296. Amherst, MA: University of Massachusetts Graduate Linguistics Student Association.

Pattillo, Kelsie E. 2013. The Typology of Uyghur Harmony and Consonants. In Rice Working Papers in Linguistics 4, ed. Penelope Howe and Benjamin Chauvette. Houston: Rice University.

Prince, Alan, and Paul Smolensky. 1993/2004. Optimality Theory: Constraint interaction in Generative Grammar. Malden, MA: Blackwell.

Roettget, T.B., B. Winter, S. Grawunder, J. Kirby, and M. Grice. 2014. Assessing incomplete neutralization of final devoicing in German. Journal of Phonetics 43: 11-25.

Smolensky, Paul. 2006. Optimality in phonology II: Harmonic completeness, local constraint conjunction, and feature domain markedness. In The harmonic mind: From neural computation to optimalitytheoretic grammar, vol. 2: Linguistic and philosophical implications, ed. Paul Smolensky and Géraldine Legendre, 27-160. Cambridge, MA: MIT Press.

Spencer, Andrew. 1996. Phonology: Theory and description. Malden, MA: Blackwell Publishing.

Vajda, Edward. 1994. Kazakh phonology. In Opuscula Altaica: Essays presented in honor of Henry Schwarz, ed. Edward H. Kaplan and Donald W. Whisenhunt, 603-650. Bellingham, WA: Western Washington University.

Warner, Natasha, Allard Jongman, Joan Sereno, and Rachèl Kemps. 2004. Incomplete neutralization and other sub-phonemic durational differences in production and perception: Evidence from Dutch. Journal of Phonetics 32(2): 251-276. 